\title{
PENGGUNAAN FORMAT BITMAP DAN VEKTOR PADA SPANDUK WARUNG MAKAN PEDAGANG KAKI LIMA
}

\author{
Ahmad Fuad \\ Universitas Esa Unggul \\ e-mail: Ahmad.fuad@esaunggul.ac.id \\ Beng Susanto \\ Universitas Esa Unggul
}

\begin{abstract}
ABSTRAK
Sudah puluhan tahun, bahkan sudah lebih dari seratus tahun yang lalu ada kebiasaan masyarakat dalam mencari rezeki dengan cara menjajakan dagangannya dipinggir jalan. Pedagang yang memiliki kebiasaan berdagang tersebut memilki istilah pedagang kaki lima. Istilah tersebut timbul dikarenakan peraturan pada zaman Hindia Belanda yang disalah artikan, "Five Foot Way" yang mengharuskan setiap bangunan besar dipinggir jalan harus menyediakan lahan sebesar Lima Kaki, untu pejalan kaki. Yang berubah pemahaman menjadi Kaki Lima. Dan lahan untuk pejalan kaki yang selebar lima kaki tersebut secara tidak sengaja menjadi tempat mangkal para pedagang keliling. Saat ini, para pedagang kaki lima pasti wajib menggunakan spanduk, sebagai tanda untuk menginformasikan tentang apa yang mereka jual. Awalnya ada hal yang menarik pada penggunaan spanduk ini. Mengapa para pedagang kaki lima, terutama pedangan Pecel Lele, Pecel Ayam dan Seafood masih bertahan menggunakan spanduk tradisional yang masih menggunakan teknik lukis manual. Selain teknik manual yang mereka gunakan, ada hal menarik lainnya yang timbul. Hal tersebut adalah mereka tetap menggunakan gambar hewan yang masih hidup, dengan gambar atau image yang tidak nyata. Dikarenakan penggunaan image yang tidak real, yang mendekati format vektor inilah yang memancing peneliti untuk meneliti penggunaan format vektor dan bitmap pada spanduk pedagang kaki lima.
\end{abstract}

Kata kunci : kaki lima, vektor, bitmap

\begin{abstract}
It's been decades, even more than a hundred years ago there was the habit of the people in seeking sustenance by peddling their wares on the side of the road. Traders who have trade habits have the term street vendors. The term arises because the rules of the Dutch East Indies era were misinterpreted, the "Five Foot Way" which requires that every large building on the side of the road must provide land of five feet, for pedestrians. And the five-foot-wide pedestrian area inadvertently becomes a hangout for mobile traders. At present, street vendors must be obliged to use banners, as a sign to inform them about what they sell. Initially there was something interesting about using this banner. Why do street vendors, especially Pecel Lele, Pecel Ayam and Seafood, still survive using traditional banners that still use manual painting techniques. In addition to the manual techniques they use, there are other interesting things that arise. This is that they still use images of animals that are still alive, with images or images that are not real. Due to the use of images that are not real, which is close to vector format, this is what provokes researchers to examine the use of vector and bitmap formats on street vendor banners.
\end{abstract}

Keywords: sidewalk, vector, bitmap

8 
Vol. 6, No. 1, Oktober 2018

\section{PENDAHULUAN}

Pedagang kaki lima, merupakan sebuah istilah untuk para pedagang yang berjualan di pinggir jalan. Merupakan kesalahan pengertian dari nama untuk para pejalan kaki di pinggir jalan raya. Di jaman Hindia Belanda, Gubernur Hindia Belanda Thomas Stamford Raflfles, memerintahkan setiap gedung di jalan utama harus menyediakan ruas untuk pejalan kaki selebar lima kaki (sekitar $50 \mathrm{~cm}$ ), dengan istilah „Five Foot Way“. Awalnya pedestrian tersebut dipakai oleh para pedagang sebagai tempat istirahat, namun ketika beristirahat banyak juga yang membeli, maka pedestrian tersebut dipakai untuk menjajakan dagangnya. Dikarenakan kesalahan pengertian hukum susunan menerangkan dan diterangkan, yang awalnya Lima Kaki, menjadi Kaki Lima. Dengan begitu sampai sekarang istilah itu masih dipakai, untuk menyebutkan pedagang yang berjualan di pinggir jalan menjadi Pedagang Kaki Lima.

Penelitian mengenai spanduk pedagang kaki lima sudah pernah dilakukan oleh Mayang Sari, untuk persyaratan kelulusan S1nya yang berjudul „KAJIAN GAMBAR DAN TIPOGRAFI VERNAKULAR PADA SPANDUK WARUNG PENYETAN DI WILAYAH SURABAYA BARAT SEBAGAI GAGASAN PENCIPTAAN HURUF (FONT)“". Dalam penelitian yang dibahas adalah tentang fenomena muncul tentang tipografi vernakular yang terdapat pada spanduk warung penyetan. Permasalahan dalam penelitian ini adalah (1) Bagaimana teknik pembuatan gambar dan tipografi vernakular pada spanduk warung penyetan. (2) Bagaimana visualisasi dan tipografi vernakular yang dig unakan pada spanduk warung penyetan di wilayah Surabaya Barat. (3) Bagaimana proses pembuatan desain huruf (font) baru yang menggunakan gambar dan tipografi vernakular penyetan sebagai gagasannya.

Untuk menginformasikan tentang apa yang dijual pada awalnya adalah dengan menyebutkan dengan cara berteriak apa yang dijual. Kemudian adanya bahasa tanda, para pedagang kaki lima membuat perbedaan tempat menjualnya. Baik itu alat pikul sebagai alat untuk membawa barang dagangannya, sampai membedakan bentuk desain gerobak. setelah ada teknologi cat, warnapun digunakan untuk memberi tanda perbedaan tentang apa yang dijual. Semakin lama masyarakat menjadi lebih pintar, dengan semakin banyak yang dapat membaca. Dengan kondisi tersebut, untuk menginformasikan tentang apa yang di jual adalah dengan memberi tulisan pada media dagang mereka, misalnya pada gerobak dan pikulan mereka.

Untuk para pedagang kaki lima yang menyediakan makanan atau minuman yang harus dinikmati ditempat, maka mereka harus menyediakan fasilitas untuk menghabiskan makanan atau minuman yang mereka beli. Maka disediakanlah tempat duduk dan meja untuk para pembeli duduk dan makan.

Untuk memberi suasana yang lebih privasi, maka para pedagang kaki lima memberi penutup dan pembatas antara lokasi berdagang mereka yang juga sebagai lokasi untuk para pembeli menikmati sajian mereka, dengan wilayah umum (DR. Ahadiat). Pembatas tersebut menggunakan kain lebar yang panjang sepanjang wilayah dagang mereka.

Kain pembatas tersebutlah yang kemudian menjadi media untuk menginformasikan tentang apa yang mereka jual, yang kemudian kami sebut spanduk pedagang kaki lima.

Sebelum ditemukan teknik digital printing, pembuatan spanduk pedagang kaki lima adalah dengan cara dilukis menggunakan kuas dan cat dengan media kain. Namun untuk sekarang ini, penggunaan digital printing sudah banyak digunakan untuk menggantikan teknik lukis spanduk.

Namun dikarenakan teknik digital masih memiliki kekurangan, selain memiliki kelebihan waktu karena proses pembuatannya cepat dan bisa memasukan objek apa 
Ahmad Fuad, Beng Susanto, Penggunaan Format Bitmap Dan Vektor Pada Spanduk Warung Makan Pedagang Kaki Lima

saja. Bahan dan umur spanduk digital lebih pendek dibandingkan spanduk kain. Satu lagi kelebihan spanduk kain adalah kemudahan untuk dilipat dan tidak mudah retak seperti spanduk digital yang menggunakan bahan lebih banyak plastik yang akan mudah retak.

\section{METODE}

Setelah melihat dari berbagai penelitian di bidang ilmu desain, maka penelitian yang menghasilkan perbandingan antara penggunaan format vector dan format bitmap pada spanduk pedagang kaki lima ini menggunakan metode penelitian terapan (applied research), dimana hasil dari penelitian ini dapat diaplikasikan langsung pada perancangan karya Desain Komunikasi Visual diantaranya perancangan untuk spanduk dan menu makanan. Hedrick, Bickman and Rog (1993) mengemukakan lima tahap dalam penelitian terapan, yaitu desain penelitian, metode pengumpulan data, jenis dan sumber data, tehnik pengolahan data dan tehnik analisa data.

\section{Penelitian Deskriptif}

Dalam menghasilkan hasil penelitian yang lengkap tentang Penggunaan format Vector dan Bitmap Pada Spanduk Pedagang kaki Lima. Penelitian deskriptif adalah yang dipakai. Hedrick, Bickman and $\operatorname{Rog}$ (1993) menyatakan, descriptive research can be designed to answer questions of a univariate that is, summarizing the relationship between two or more variables. Penelitian secara deskriptif ini adalah yang dapat menggambarkan mengapa digunakan format vector dan bitmap untuk spanduk pedagang kaki lima.

\section{Obyek dan Subyek Penelitian}

Yang menjadi obyek utama dalam penelitian ini adalah hasil karya spanduk lukis yang memiliki gambar hewan yang masih hidup dengan format vector yang biasa dipakai, dengan cara dilukis secara manual. Dan dibandingkan dengan spanduk digital yang dengan kelebihan teknologi digital dapat memasang image hewan hidup dengan format bitmap. Sedangkan subyek penelitian adalah para pembuat spanduk lukis Lamongan, yang kebanyakan memiliki kemampuan itu dari belajar dengan para seniornya.

\section{Sampel Penelitian}

Tempat untuk mengambil data penelitian adalah pengrajin spanduk lukis Lamongan dan para pedagang kaki lima yang menggunakan spanduk lukis lamongan, spanduk lukis brebes, dan spanduk lukis tegal. Penelitian juga dilakukan dengan memesan spanduk lukis, dengan gambar yang sesuai dengan foto yang akan dibandingkan di pak Sutrisno Hatta yang memiliki workshop di daerah Cikande, Serang, Banten.

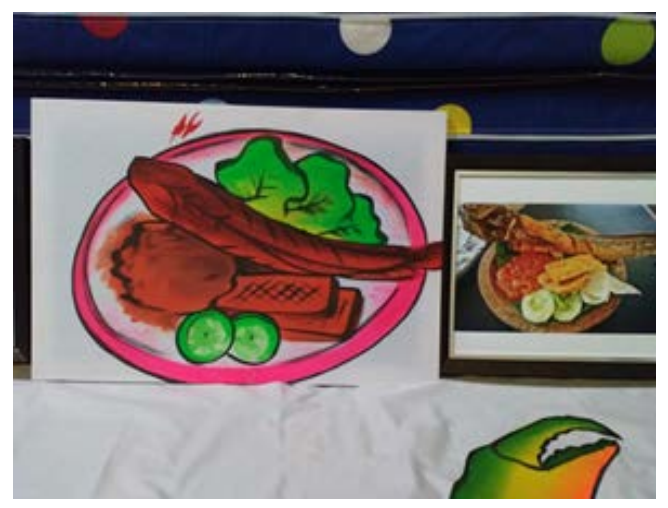

Gambar 1.

Perbandingan format vektor dan bitmap untuk makanan matang

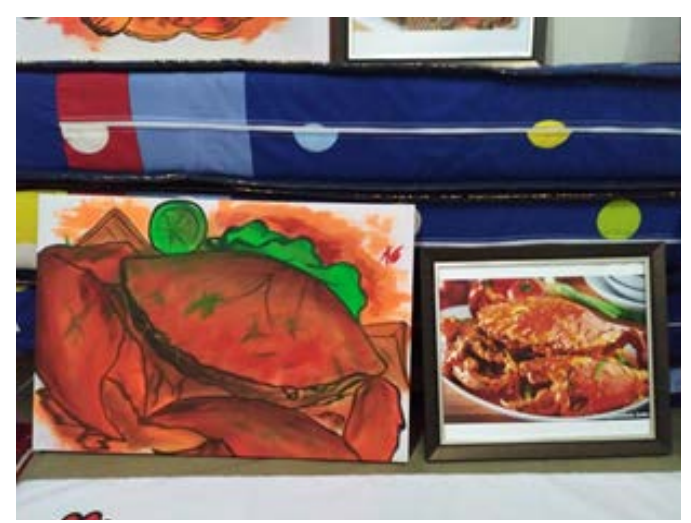

Gambar 2. Perbandingan format vektor dan bitmap untuk makanan matang 
Lukisan lukisan diatas adalah lukisan dari pelukis spanduk Lamongan dengan cara memberikan contoh foto makanan jadi, kemudian dilukis dengan teknik dan kemampuan serta kebiasaan melukis mereka, tanpa instruksi dan masukan dari peneliti tentang cara melukis ataupun kesan yang ingin dicapai agar visual komunikasinya sampai.

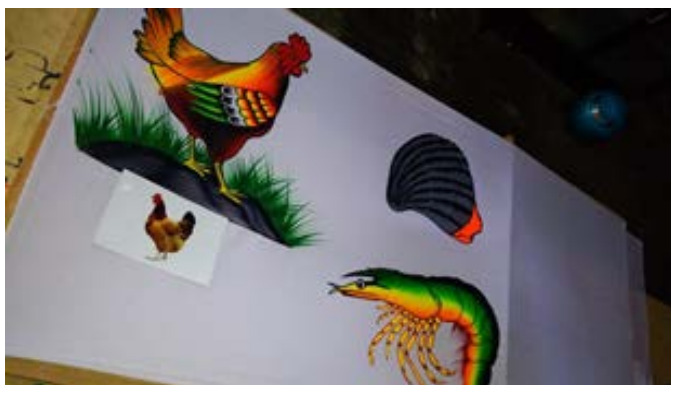

Gambar 3

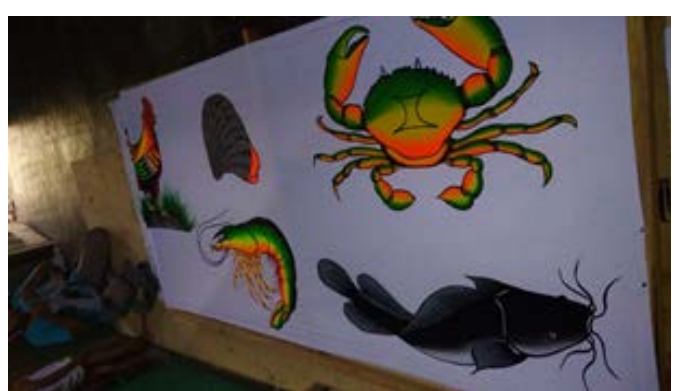

Gambar 4.

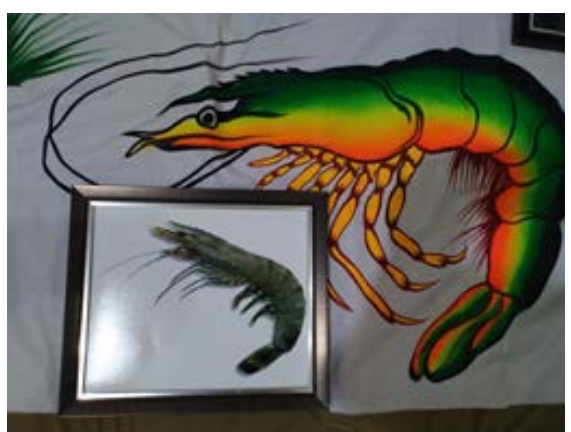

Gambar 5

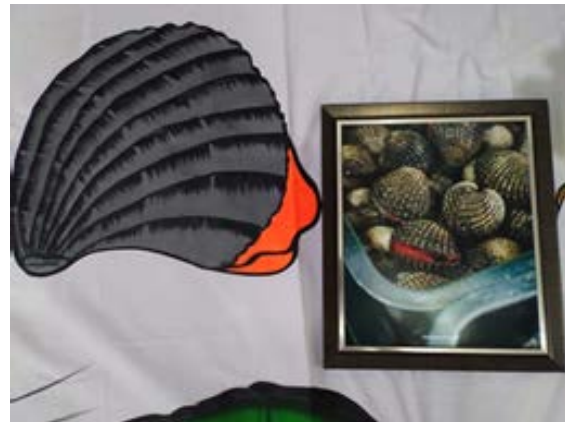

Gambar 3-6. Perbandingan format vektor dan bitmap untuk hewan yang belum matang

Begitu juga dengan format vector, dengan memberikan contoh gambar hewan hidup, menjadi gambar hewan dengan menggunakan teknik lukis langsung di spanduk.

\section{Diskusi}

Wawancara dan diskusi digunakan sebagai metode yang dilakukan oleh Tim Peneliti melalui forum group discussion dengan para narasumber dan melalui indepth interview dengan pemilik workshop Spanduk Lukis Lamongan dan Fakultas Psikologi Universitas Esa Unggul. Instrumen pengumpulan data yang digunakan adalah pedoman wawancara.

\section{Observasi}

Metode observasi dilaksanakan melalui pengamatan langsung di lokasi workshop pembuatan Spanduk Lukis Lamongan. Tim Peneliti mengamati proses lukis spanduk, dari pembuatan sketsa gambar dasar hewan yang akan menjadi objek yang jual, dan hasil pengamatan digunakan sebagai data penunjang dalam penelitian.

\section{Dokumentasi Fotografi}

Dokumentasi berupa foto-foto hasil spanduk lukis lamongan merupakan jenis data primer yang paling penting dalam penelitian ini. Oleh karena itu, instrumen pengumpulan data yang digunakan adalah mendokumentasikan spanduk-spanduk lukis melalui fotografi, dan membadingkan. 
Ahmad Fuad, Beng Susanto, Penggunaan Format Bitmap Dan Vektor Pada Spanduk Warung Makan Pedagang Kaki Lima

Studi Literatur

Literatur tentang spanduk lukis tidak banyak tersedia, oleh karena itu Tim Peneliti menggunakan studi wawancara dan berbagai sumber sebagai sumber informasi penunjang dalam penelitian ini.

\section{Data Sekunder}

Data sekunder merupakan data yang secara tidak langsung memberikan data pada tim peneliti. Sumber data sekunder diperoleh melalui berbagai literatur dan dokumentasi yang membahas tentang penggunaan format vector dan format bitmap di spanduk lukis untuk para pedagang kaki lima.

\section{Triangulasi}

Triangulasi merupakan tehnik pengujian keabsahan data. Oleh karena itu, data-data penelitian yang diperoleh melalui wawancara, observasi, dokumentasi dan literatur selanjutnya diuji melalui tehnik triangulasi, sehingga diperoleh keabsahan informasi tentang mengapa spanduk warung pedagang kaki lima menggunakan format vector untuk jenis hewan yang dijual dalam kondisi hewan hidup di semua karya lukis spanduknya .

\section{Reduksi}

Reduksi data digunakan dalam penelitian ini adalah untuk mengatur data-data yang telah didapat, antara lain melalui proses pemilihan, penggolongan, penyederhanaan, dan membuang data yang tidak diperlukan. Pada penelitian ini, berbagai sumber data difokuskan pada data tentang mengapa digunakan format vector untuk menunjukan hewan yang akan digunakan sebagai bahan dasar masakan yang akan dibuat dalam kondisi hewan tersebut masih dalam keadaan hidup, dan dengan format bitmap jika makanan yang dijual tersebut dalam keadaan matang. Tehnik reduksi data ini dilakukan terus menerus hingga laporan akhir penelitian selesai.

\section{Penyajian Data}

Penyajian data dalam penelitian ini dirancang untuk menggabungkan berbagai informasi tentang alasan penggunaan format yang tepat untuk spanduk lukis warung pedagang kaki lima.

\section{Penarikan Kesimpulan}

Data-data penelitian tentang penggunaan format yang tepat dalam membuat spanduk warung pedagang kaki lima, dilakukan melalui tinjauan data yang berulang-ulang selama proses penelitian hingga penarikan kesimpulan hasil penelitian.

\section{Tehnik Analisis Data}

Wawancara, observasi, dokumentasi fotografi, dan studi literatur digunakan dalam proses analisis data dimulai dengan meneliti seluruh data yang diperoleh. Untuk mendapatkan hasil tentang alasan penggunaan format gambar vector atau format gambar bitmap yang tepat. Foto - foto hewan hidup dan makanan jadi yang menggunakan format bitmap diperlukan untuk membandingkan antara karya lukis spanduk warung pedagang kaki lima yang membuat gambar hewan hidup dan makanan jadi yang berupa format vector, tapi dibuat secara manual. Martin and Hanington (2012) menyatakan, artifact analysis is a systematic examination of the material, aesthetic, and interactive qualities of objects contributes to an understanding of their physical, social, and cultural contexts.

Langkah selanjutnya merupakan proses pengetesan perbandingan apakah dengan objek gambar yang sama, akan tetapi menggunakan format yang berbeda, dapat menghasilkan kesan yang berbeda. Tahap akhir dari analisis data adalah tahap membuat penafsiran data menjadi substantif dalam penelitian ini. 


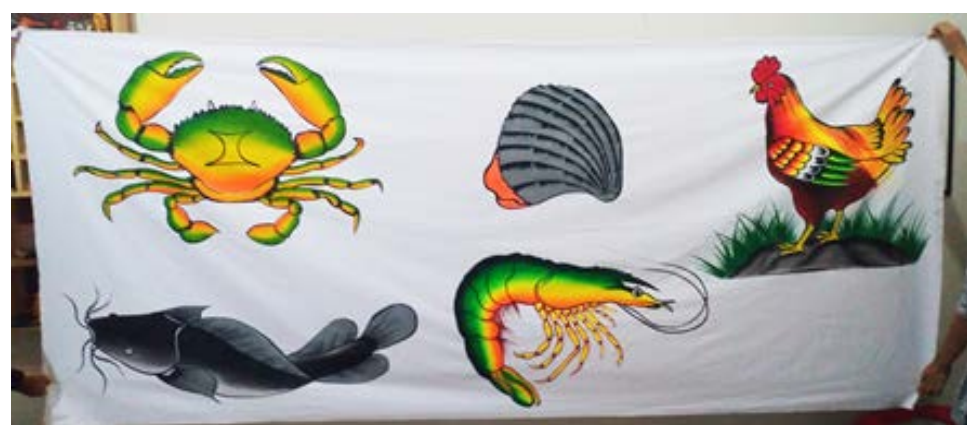

Gambar 7. Spanduk pedagang kaki lima dengan format vektor untuk objek hewan dalam kondisi masih hidup

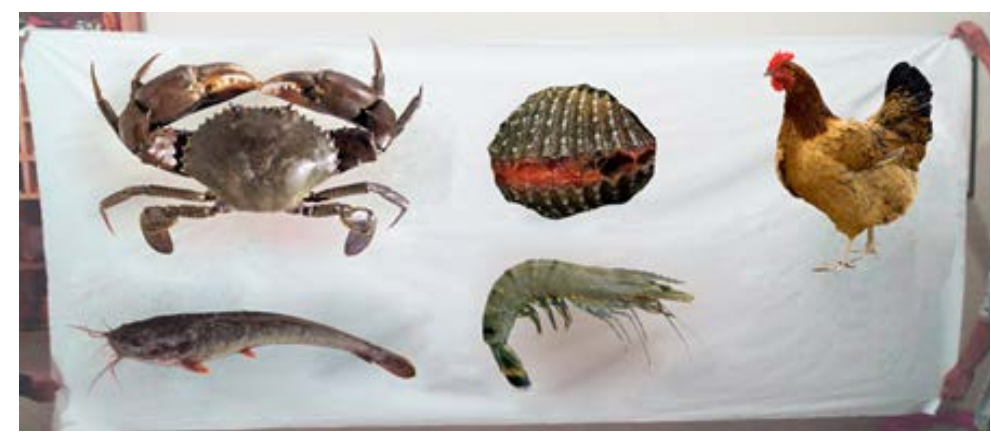

Gambar 8. Spanduk pedagang kaki lima dengan format bitmap untuk objek hewan dalam kondisi hidup

Dapat kita lihat di gambar 7 dan 8 , spanduk dengan format bitmap memberi kesan barang yang didagangkan adalah hewan hidup. Berbeda dengan yang menggunakan format vektor, selain karena kebiasaan, spanduk dengan format vektor tidak memberi kesan nyata. Jadi dengan spanduk dengan format vektor, tidak akan mengganggu mengenai apa yang didagangkan.
Penggunaan format bitmap di Buku Menu untuk menunjukan jenis hewan hidup yang disajikan

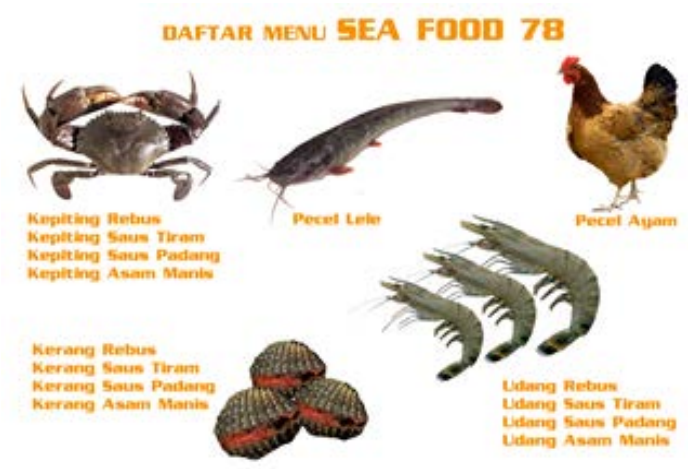

Gambar 9. Menu dengan objek hewan hidup dengan format bitmap 
Ahmad Fuad, Beng Susanto, Penggunaan Format Bitmap Dan Vektor Pada Spanduk Warung Makan Pedagang Kaki Lima

Jika penggunaan format bitmap dengan objek hewan hidup pada buku menu ini ada beberapa permasalahan yaitu :

1. Efek dari format bitmap yang memberikan gambar asli dari binatang memberi kesan yang tidak higienis

2. Penggunaan Art Directing yang tidak sesuai dengan Copywriting, dimana tertulis Kerang rebus, yang tergambar kerang hidup.

3. Image yang terlihat tidak bisa mengundang selera.

Penggunaan format bitmap di Buku Menu untuk jenis hewan yang sudah matang

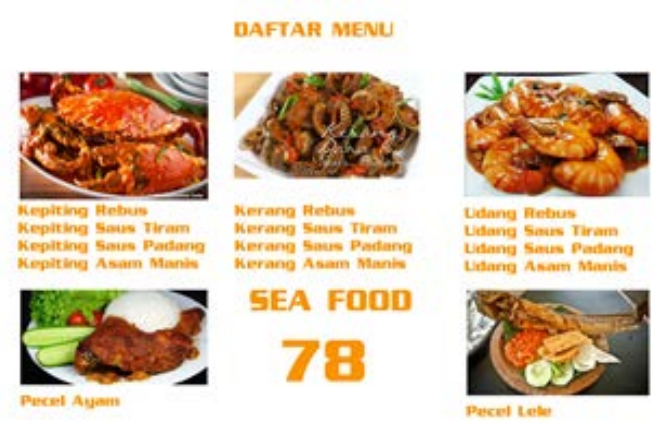

Gambar 10. Menu dengan objek makanan jadi dengan format bitmap

Penggunaan format bitmap akan lebih efektif jika digunakan untuk objek makanan yang sudah matang, selain itu ada kesesuaian antara Art Directing dengan Copy Writing. Objek gambar sesuai dengan informasi yang tertera di media.

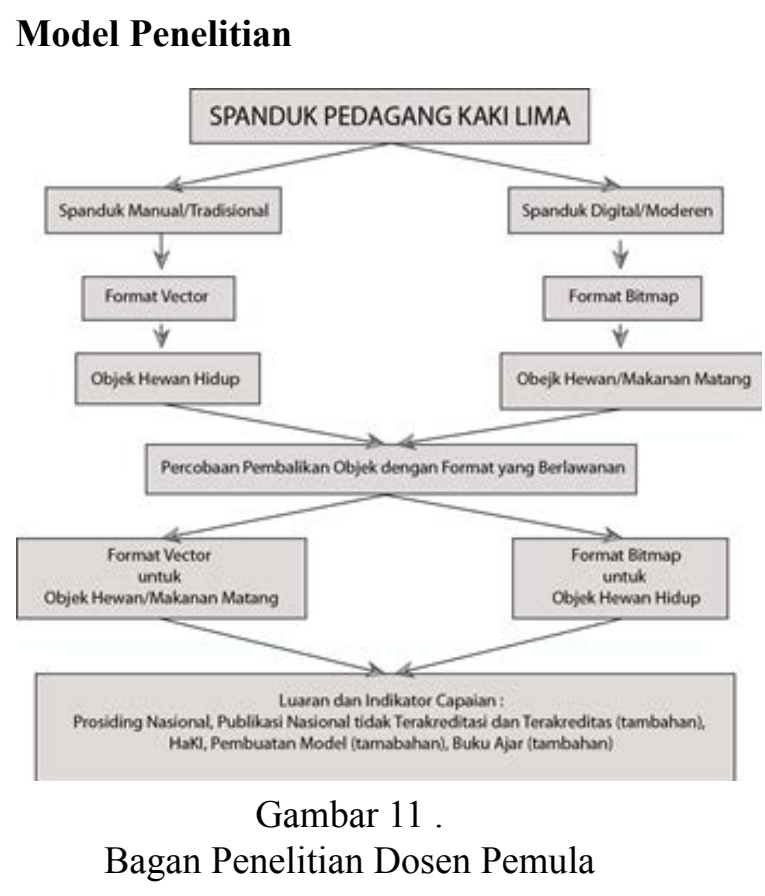

\section{Kesimpulan}

Hasil survey penelitian ini menunjukan bahwa Penggunaan format vektor pada spanduk pedagang kaki lima adalah tepat, jika yang ditunjukan adalah hewan yang dijual untuk menu makanannya dalam keadaan hidup.

Untuk penggunaan format bitmap, sebaiknya digunakan untuk objek makanan yang matang. Jika objek yang digunakan adalah foto hewan yang hidup, kesan yang didapat adalah kesan tidak higienis. Kesan bulu berterbangan, lengketnya lendir ikan lele, bau amis kepiting itu seperti terasa.

Dengan menggunakan spanduk lukis buatan tangan ini, kesan originalitas dari sebuah rasa akan lebih baik. Selain itu pendapatan para pelukis spanduk inipun dapat bertahan, dan yang lebih penting lagi kebudayaan lukis spanduk baik itu yang berasal dari Lamongan, Brebes, Tegal dan masih banyak lagi kota yang membuat dapat bertahan. 
Daftar Pustaka

Direktorat Jenderal Penguatan Riset dan Pengembangan Kementerian Riset, T. d. ((2017)). Panduan Pelaksanaan Penelitian dan Pengabdian Kepada Masyarakat di Perguruan Tinggi Edisi XII.

Hedrick, T. E. ((1993).). Applied Research Design. A Practical Guide. California:: Sage Publications.

Itten, J. (1970). The Elements of Color. . New York: Van Nostrand Reinhold Company. Martin, B. \&. ((2012)). . Universal Methods of Design. Beverly: : Rockport Publishers. mayang sari. (2013). M Sari - Jurnal Seni Rupa, 2013 - jurnalmahasiswa.unesa.ac.id. Retrieved from http://jurnalmahasiswa.unesa.ac.id/index.php/va/article/view/9778: https:// media.neliti.com/media/publications/246574-kajian-gambar-dan-tipografi-vernakular-p-0aa99e15.pdf 